\title{
MIR4457 Pre-miRNA
}

National Cancer Institute

\section{Source}

National Cancer Institute. MIR4457 Pre-miRNA. NCI Thesaurus. Code C118123.

MIR4457 pre-miRNA (68 bases) is encoded by the human MIR4457 gene. This

oligoribonucleotide may play a role in the neg ative regulation of gene transcription. 